\title{
"Narrative Cloggers": Notes on Description and Subversion in Nicholson Baker's Fiction
}

\section{Françoise Sammarcelli}

\section{(2) OpenEdition \\ Journals}

Electronic version

URL: https://journals.openedition.org/ejas/9996

DOI: $10.4000 /$ ejas. 9996

ISSN: 1991-9336

Publisher

European Association for American Studies

\section{Electronic reference}

Françoise Sammarcelli, "'Narrative Cloggers": Notes on Description and Subversion in Nicholson Baker's Fiction", European journal of American studies [Online], 8-1 | 2013, document 2, Online since 27 May 2013, connection on 08 July 2021. URL: http://journals.openedition.org/ejas/9996 ; DOI: https:// doi.org/10.4000/ejas.9996

This text was automatically generated on 8 July 2021.

Creative Commons License 


\title{
"Narrative Cloggers": Notes on Description and Subversion in Nicholson Baker's Fiction
}

\author{
Françoise Sammarcelli
}

1 In his essay on John Updike printed in 1991, Nicholson Baker wrote : "[...] the only thing I like are the clogs. I wanted my first novel to be a veritable infarct of narrative cloggers, the trick being to feel your way through each clog by blowing it up until its obstructiveness finally revealed not blankness but unlooked for seepage-points of passage..." (72) Born in 1954 in Massachusetts, Baker has sometimes been compared to Georges Perec and Steven Millhauser because of his narrators' obsessive interest in apparently inconsequential details. Baker used to work as a technical writer and it certainly shows, as his novels offer innumerable close-ups on potentially banal objects (such as doorknobs, tires, straws, staplers, paper clips, jars of peanut-butter, etc). I will argue that these proliferating descriptive passages function as "narrative cloggers" indeed, as they seem to short-circuit narrative progression instead of being mere additives to the narrative, in a textual exploration which blurs the traditional distinction between description and narration.

2 I will focus on three of Baker's novels and this will allow me to comment on the evolution in Baker's work between 1988 and 2003, from the exuberant description of objects in The Mezzanine (1988), to a more intimate rehistoricizing of the object as a trace of the narrator's experience as a family man in Room Temperature (1990), to the repeated encoding of daily life as an ever-renewed mystery in A Box of Matches (2003).

Dwelling on the various strategies at work in Baker's descriptions (such as his frequent experiment with conjunction and disjunction, or his particular use of metaphor and metonymy), this paper will also show how the humorous defamiliarization of the visible contributes to the resistance of the texts. From the emphasis on material objects (and the body) to that on the materiality of signifiers, this will lead to a discussion of the metatextual dimension of description. 
4 According to various theorists of "realist" discourse such as Philippe Hamon, the "realist" universe (as opposed to the world of fantastic discourse) is describable, accessible to denomination; in this system, description is seen as contributing to verisimilitude and ensuring readability. ${ }^{i}$ While slowing down the rhythm of the narrative proper, it supposedly provides what Roland Barthes called a "reality effect". However, Baker's novels transgress this rule insofar as description comes to the foreground in an obtrusive way and often functions as digression. The referential illusion seems to be undermined by the hypertrophy of descriptive segments which also questions the boundaries between interiority and exteriority, objectivity and subjectivity. Here the didactic impulse inherent in the realist program is combined with a tension toward exhaustivity that disturbs the balance. Additionally, Baker's hybrid or even bombastic diction, his incongruous association of recherché words or sometimes even neologisms with ordinary words, or his use of pompous polysyllabic adverbs, also precludes the naturalization of description-"despite this sort of periodic metascruple, I certainly helped myself to the paper towels" (Mezzanine 93), "I was able to make the roll trundle momentumously around the spindle" (Mezzanine 75)-while, quite often, comparisonis conveyed through abstract nouns that point to a quality, such as "the deformability of my bottom, the pillowness of my sweater" (Room Temperature 10). They deal with the body as with an industrial product, but also underline the text's own artificial quality.

5 In The Mezzanine, Baker's first novel, the descriptive passages are all the more conspicuous as most of them are offered in footnotes, to such an extent that these footnotes seem to compete in volume with the body of the text: thus a note on grooved surfaces takes up four pages (65-68), but there are also long notes on straws (4-5, resumed on 94), on doorknobs (27-28), on perforation (74-75), on cups and mugs (78-79). Through this paratextual inflation, the text draws our attention to its own nonunified surface. Moreover, in this novel, the dynamic of digression is also to be found within individual footnotes which often shift from one topic to another: for instance, what starts as a note on doorknobs metonymically moves on to a note on the narrator's father's habit of draping his ties on doorknobs, and so on (27-28). Digressions therefore debunk linearity.

6 Almost nothing happens in Baker's novels, which de-emphasize traditional aspects of the plot. The Mezzanine records its narrator's thoughts during a ride on an escalator and explores all the commonplaces of office life. In Room Temperature the narrator is stationary as he is feeding his baby daughter, so the diegetic time is apparently very short, even though the text often resorts to analepsis. In A Box of Matches, a different static effect is produced by the protagonist's ritual actions as he gets up early every morning, lights the fire and makes coffee.

7 Yet all sorts of adventures and short fictional episodes are to be found within these novels. In The Mezzanine, the long description of grooves, starting from the office escalators (65-68), ends with a micro-narrative, the story of a journey, relying on analogy and metaphor. Thus description, which contaminates the narrative, is itself contaminated by narrative elements. Owing to a change of scales, the text achieves a defamiliarization which involves the poetic transformation of a formerly banal experience (that of listening to the end of an LP record) into an exotic one :

[...] You had now entered the microscopic spell of the technology [...] you rode the last grooves as if on a rickshaw through the crowded Eastern capital of the music, and then all at once, at dusk, you left the gates of the city and stepped into a 
waiting boat that pulled you swiftly out onto the black and purple waters of the lagoon, toward a flat island in the middle; rapidly and silently you curved over the placid expanse, drawing near the circular island (with its low druidic totem in the middle, possibly calendrical) but never debarking there; now the undertow bore you at a strange fluid speed back toward the teeming shore of the city-colors, perspiration, sleeplessness-and then again back out over the lagoon; the keel bumped first one shore, then the other, and though your vessel moved very fast it seemed to leave only a thin luminous seam in the black surface behind you to mark where the keel had cut. Finally my thumb lifted you up, and you passed high over the continent and disappeared beyond the edge of the flat world. (Mezzanine, 68)

Critics have often commented on Baker's combination of intellectual playfulness and lyricism. Indeed, this iterative account is not quite devoid of the comic dimension to be found in many other descriptive sections, while a shared experience is artfully transposed into a quasi-metaleptic tale. The referential quality does not disappear (one is likely to identify the "totem," etc), but the text, like the imagined traveller's journey, seems to get out of the groove indeed. At the same time one cannot miss the seductive quality of the fluid prose (due to the clever distribution of stresses, the harmonious alliterations and assonances- for instance the insistent $[\mathrm{k}]$ and [d] sounds, the recurrent [i :] in speed, teeming, sleeplessness, keel, seemed, seam) and its evocative images. The "spell of the technology" is thus echoed in the magic of words and sounds. As suggested in the quotation from $U$ and I, the clog may become a "point of passage," but the return of the first person at the end ("my thumb lifted you up") also points to the solitary power of the creator, the one who manipulates the signs and arbitrarily moves from one scale of reality to another.

9 As Ross Chambers remarked, "While without 'event' in any traditional sense, [The Mezzanine] moves forward, escalator-like, through a continual unfolding of one topic out of another, and of thoughts out of things" (Chambers 768). Events can thus be redefined as adventures of the mind, reminiscences and thought processes reflexively commented upon, and objects are stimuli in this minute inspection of the stream of a man's thoughts. Instead of building a plot, Baker's homodiegetic narrators rely on effects of contiguity as they expatiate on the details of artefacts and techniques, and above all on our (individual or collective) experience of them, since it is a matter of interaction or encounter between the self and the objects. As the narrator of The Mezzanine puts it, "An unpretentious technical invention -the straw, the sugar packet, the pencil, the windshield wiper-has been ornamented by a mute folklore of behavioral inventions, unregistered, unpatented, adopted and fine-tuned without comment or thought." (95) Thus the texts claim to fill a gap by examining those ordinary things that most people overlook, and comically elevate them to the status of memorable items.

Words denoting an intellectual process ("I think", "I studied") or the activity of memory ("I remembered", "I recalled", "it reminded me") function as narrative shifters. Description is necessarily subjective, mediated by an individual consciousness, though the individual experience may be part of the collective one in a sometimes anthropological perspective. But "Why do these images have to age before we can be fond of them?" (The Mezzanine 78). In a review of his 1992 novel Vox, Baker was called a "quantum suburban Proust" (Stengel 59), and it is true that his novels could be read as a new kind of Remembrance of Things Past, trying to recapture the past on a microscopic level or to write a nostalgic history of America over the last decades through the evolution of its artefacts (as, on a different level, the narrator of Room Temperature 
reads the history of his family in a recycled jar of peanut-butter). In The Mezzanine the narrator dwells on playful reminiscences but warns us that "the determinism of reminding often works obscurely" (69). But, whereas for Proust "the past is hidden [...] beyond the reach of intellect, in some material object (in the sensation which that material object will give us) which we do not suspect" (Swann's Way 57-58), for Baker it is not concealed and, on the contrary, interiority can be exposed and objectified. The object is not construed as other but as part of the experience of the self, and as such deserves to be preserved.

After his first novel, Baker reintroduces the potential content of the footnotes into the text itself, but this does not preclude a remarkable exploration of the hierarchy of discourse. In Room Temperature, the text branches off into innumerable digressive units. On the formal level, destabilization is often emphasized by a greater intricacy of syntax, which looks almost Proustian in its piling up of adverbial and relative subordinate clauses and appositions: for instance in Room Temperature the protagonist devotes a very long sentence to Debussy's music and his own somewhat burlesque reflexions on the mimetic effect achieved in La Mer (52).ii While couched in simpler terms, the descriptive digressions in A Box of Matches are not more justified. The narrator thus casually introduces the reference to his fireplace: "It occurs to me that I haven't described the fireplace. It isn't a Rumford fireplace. [...] This fireplace is almost a Rumford, but it is an earlier design" (93).

Relying on repetition and difference, structured around its narrator's ritual, A Box of Matches also seems to go one step further in recontextualization, as the interaction with the familiar objects is often complexified by the absence of light (in that case the narrator gropes his way toward the objects instead of seeing them). The narrative therefore also focuses on tactile perception, and not only on visual signs. Far from the technical digressions of the other novels, the simplest object acquires a singular status. Knowledge, or a new kind of intimacy, comes from practice, as the narrator explains about his self-imposed task of making coffee in the dark:

Making coffee in the dark [...] is a skill that improves with practice. First you pull out the old filter, with its layer of coffee sludge, and pin its sides together like a soft taco so that you can get it safely into the garbage can without spilling, and then you rinse out the filter basket and the carafe, taking special care to clean the little hole in the plastic top of the carafe, which is like the hole in the top of a baby's head, where the coffee tinkles down from the basket and into the baby's brain. And you stretch the fluted mass of paper filters so that your fingers can feel and take hold of one layer-a sensation similar to turning the pages of an eighteenth-century bookand you settle the filter in the basket so that none of its sides are likely to flop over, allowing the water to flow around the coffee without drawing out its liquor. [...] (A Box of Matches 16-17)

13 The use of anaphoric articles (the old filter, the plastic top of the carafe...) pointing to pre-constructed elements first conveys a sense of the familiar. One is all the more surprised by the unexpected comparison between the hole in the carafe and the hole in a baby's head-even more so as the simile soon turns into a metaphor, which erases the difference between the inanimate and animate elements in a disquieting and somewhat surrealistic way ("the coffee tinkles down from the basket into the baby's brain"). Simultaneously, the imagined porosity of the baby's head may remind us of Baker's interest in seeping effects. 
14 According to the narrator, the text is deceptive as perceptions are often "more incremental than you later are tempted to present them as being" (Mezzanine 8-9). Indeed, on a first reading, disjunction often seems to prevail in Baker's novels and, in that respect, the frequent use of lists, those minimal forms of organization, lays bare the device by suggesting a refusal of order. TheMezzanine thus offers a list of systems of local transport (35-36), or more schematically a list of "major advances" in the protagonist's life (16), or even more comically, the "list of mid-frequency ideas" which the narrator imagines "in the form of a chart" in a parodic attempt to objectify his mental life (127-128).

Within the descriptive passages, effects of syntactic disjunction are also to be observed as the text exploits the power of "or ... or..." sequences as a way toward the right form. The narrator of Room Temperature thus records his striving toward the sensation of insideness required to draw the inside of a pillow:

I needed to catch in the sketch some of the sensation of reaching inside a new chicken and pulling out the giblets; or of reaching into the dryer to pull out hot clothes; or of scraping the seeds from a melon or pulling the cheap gift out from the bottom of a box of Rice Krispies, or of plunging a knife into a new jar of peanut butter [...] (RT 55)

Constructing or approximating the unfamiliar requires the activation of various already-experienced sensations.

Predictably, punctuation itself can also be construed as a tool of disjunction. Yet even the shape of the comma cannot be described simply, and it triggers off a whole series of associations as the text expands through baroque accumulations of images: "it recalled the pedals of grand pianos, mosquito larvae, paisleys, adult nostril openings, the spiraling decays of fundamental particles, the prows of gondolas, half-spent tubes of antifungal ointment, falcon or airplane wings in cross section..." (RT 66).

Yet, in a sense, anything may be used to suggest the details of an entire life; disjunction may lead to conjunction while the narrators are groping toward a sense of totality. The narrator of Room Temperature expresses his belief that

with a little concentration one's whole life could be reconstructed from any single twenty-minute period randomly or almost randomly selected; that is, that there was enough content in that single confined sequence of thoughts and events and the setting that gave rise to them to make connections that would proliferate backward until potentially every item of autobiographical interest [...] could be at least glancingly covered; but [...] the particular cell you started from colored your entire re-creation. (41)

19 Not just one, but innumerable reconstructions are possible, like so many variations on the reconfiguring power of imagination.

20 Concerned with the complexities of intimacy, Room Temperature often blurs the limits or subverts the inside/outside polarities. In that regard the comic scene in which the protagonist walks through an enlarged model of a human heart in a science museum (100) is emblematic: the protagonist experiences claustrophobic panic, while the reader smiles at this recycled cliché of fantastic fiction. The text thus makes fun of its own pedagogic tendency while literalizing the reversal of perspective.

21 Various tasks-like drawing the inside of a pillow (Room Temperature 54-56)-also relate to this dynamic. The narrator remembers his sense of an intellectual challenge: "the impossible mental involution of attempting to imagine one's pencil investigating the 
poorly lit interior surfaces of one's own pillow" (54). In this case, mediation and distance are suggested by the series of abstract polysyllabic words, so that syntax mimics the difficulty of reaching the essence of the object. Yet, in this context, obstacles, like narrative cloggers, may lead to possible exchanges. Unable to find a satisfying equivalent, the boy cheated and drew a sketch which emphasized circulation and thus provided a metonymic representation: "a primitive pair of lungs [...] and an arrow pointing to them that said 'From a pillow'; for as I explained to my mother, the only way to know the real nature of the inside of a pillow was to breathe its air" (56). More reflexively, commas are later praised because they do not prevent the circulation of meaning: "their newer shape nonetheless manages at least to evoke the rubber doorstop's dependable amenity, keeping the ostioles ${ }^{\text {iii }}$ free from clause to clause, allowing metaphors to mix more freely" (67). Between typographical signs and material objects, images themselves keep circulating, offering unexpected insights into the art of metamorphosis.

Likewise, the description of the narrator's sweater in the beginning of the novel is paradigmatic as it stresses both the complexity of its pattern and its blurred limits, its subtle fading into its environment:

Also as a result of the weather, I was wearing a sweater for the first time in months, one Patty had given me for my birthday: a brown monster stout with various fugal inversions and augmentations of the standard cable knit, and consequently glutted with insulational dead air, its corona of lighter outer fibers frizzing out threeeighths of an inch or more from the slubbed and satisfyingly clutchable weave that formed the actual structure underneath, so that the sweater, along with me, its wearer, appeared to fade without a demonstrable outer boundary into the rest of the room, as tuning forks or rubber bands will seem in their blurred vibration to transform their material selves into the invisible sound they generate; a machinemade sweater, but manufactured apparently with Xenakian lurches and indecisions programmed into the numerically controlled needles [...]. (Room Temperature 4-5)

The text combines rich visual and musical images, but is also endowed with a metatextual quality. While the technical terms may function as playful deterrents, challenging our ability to visualize the object, the musical terms provide other clues, whether used metaphorically ("fugal inversions," "with Xenakian lurches,") or by analogy ("as tuning forks [...] into the invisible sound they generate"). Thus the sweater may function as a metaphor for the text itself, insofar as it flaunts its qualities as a beautiful artefact with its numerous threads and interwoven motifs. One may also find a certain metatextual relevance in the allusion to the fugue and, more significantly, in the reference to Xenakis, a composer associated both with computer music (clearly alluded to at the end of the excerpt) and to concrete music (equally inspiring for Baker since it involves sounds of all types, musical, natural, human, mechanical, etc, which, recorded on tape, are filtered or manipulated-a method which the text seems to transpose on a humbler scale).

More generally, as Claire Fabre pointed out, Baker's text keeps weaving together its pet motifs, transforming the object it describes into a metaphor, which in turn becomes the vehicle for a new metaphor (Fabre 119). Thus the term "escalator" itself may be used figuratively. Even "the Bug," the narrator's baby daughter, is referred to metaphorically in terms of suspension and punctuation: "The breathing Bug [...] was my comma" (77). In that respect, the magnifying glass mentioned in the last chapter (114) provides another metaphor for the functioning of the whole text, with its ceaseless changes of scale and its use of enlarging effects. 
This reflexive game raises the issue of signification, and the reader may wonder if some of the descriptions are not "purely decorative," like the recycled jar of peanut-butter with its assortment of "not-quite pencils" in which nothing can be moved (114). Or does description, like the painstaking reconstruction of a broken object, or the interaction with a household object in the dark, open a new range of signification(s)? In Room Temperature, the narrator comments on his privileged connection with a broken object: "in repairing the object you really ended up loving it more, because you now knew its eagerness to be reassembled, and in running a fingertip over its surface you alone could feel its many cracks-a bond stronger than mere possession" (29). Projecting intention and subjectivity on the object ("its eagerness") and enhancing his affective relationship with it, the narrator departs from the more technical point of view of The Mezzanine. Re-membering is obviously a way to remember and depth may be found on surfaces, while the emphasis on bodies or material objects also leads to the materiality of signs.

Meanwhile, the frequent references to sound and music on the one hand, and surfaces (whether grooved, gritty, or smooth) on the other, suggest an insistent exploration of signifiers. The long passage devoted to commas and their "civilizing power" in chapter 9 of Room Temperature provides an extreme example of this fascination for signs (66-77), as the narrator considers writing a treatise on commas and indulges in a whole series of learned or mundane associations (72).

The texts evince a metatextual dimension as the self-conscious narrators draw our attention to stylistic effects and the limits of representation, while also offering references to codes (see the clichés of social exchanges described in The Mezzanine, down to the most trivial details, as in the note on "oop" and "oops" [82]), to oral and written linguistic forms, and even to the sound of writing, when the narrator of Room Temperature tries to guess what his wife is writing in her diary by listening to the sound of her felt-tip pen on the page: "I listened even harder to Patty's writing", "thinking about how Patty's writing sounded” (19-21). Banal words themselves, like everyday objects and routines, are duly examined and nothing is taken for granted. Thus the narrator of A Box of Matches comments on the phrase "striking a match":

think of that word, struck, which stores within it the old form of fire-lighting: we now swipe a match [...] whereas once, before matches, we must truly have struck a flint [...] As I remember, the hard-boiled detective novels have characters who 'scratch' a match, which is a good way of saying it (50).

One could argue that the rediscovery of form is particularly eloquent in the context of the quietness and uncrowdedness of this novel.

From dissecting to remembering, description, like quotation, is perhaps always a matter of framing. In The Mezzanine, the narrator reflexively comments on what he calls "the clean-background effect" which helps to set off an object :

[...] I remembered that when I was little I used to be very interested in the fact that anything, no matter how rough, rusted, dirty, or otherwise discredited it was, looked good if you set it down on a stretch of white cloth, or any kind of clean background [...]. This clean-background trick [...] applied not only to things I owned [...] but also to things in museums [...] because anytime you set some detail of the world off that way, it was able to take on its true stature as an object of attention. [...] on their own, olives are old, pickled, briny, rusty-but set them off against a background of cream cheese and you have jewelry. (Mezzanine 38-39)

This passage, inspired by a green garbage truck against a backdrop of clear blue sky on the highway, may be read as a comment on Baker's own technique. In other words, his 
strategy is both aesthetic ("anything ... looked good") and hermeneutic (revealing the "true stature" of the object), while the specific context is supposed to justify the closeup- yet, lest we should take this tenet too seriously, Baker ambiguously provides an eloquent illustration (39).

Detail after detail, a world is reconstructed-but it is primarily a world of words. An incremental dynamic is at work and one may therefore also reconsider the initial question of the relationship between description and narration in Baker's prose. In his work the descriptive section is not really a pause and it never quite escapes the temporality of history. All in all, Baker's sophisticated fiction may prove surprisingly coherent in its exploration of (points of) passage-that is, of transformation and ways through the crowded realm of the real, allowing for singular forms of circulation and recirculation.

\section{BIBLIOGRAPHY}

BAKER, Nicholson. The Mezzanine. New York, Weidenfeld \& Nicholson, 1988; repr. New York, Vintage, 1990.

---. Room Temperature. New York, Grove Weidenfeld, 1990; repr. New York, Vintage Contemporaries, 1991.

-- - U and I: A True Story. New York, Random House, 1991; repr. London, Penguin/Granta Books, 1991.

---. A Box of Matches. New York, Random House, 2003 ; repr. New York, Vintage, 2004.

BROOKE-ROSE, Christine. A Rhetoric of the Unreal. Cambridge UP, 1981.

CHAMBERS, Ross. "Meditation and the Escalator Principle (On Nicholson Baker's The Mezzanine)". Modern Fiction Studies 40, 1994, 765-806.

FABRE, Claire. « Aux frontières de l'intime : l'intériorité exhibée dans Room Temperature (1984) de Nicholson Baker ». RFEA 109, September 2006, 113-121.

HAMON, Philippe. "Un discours contraint”, Poétique 16, 1973. Repr. in R. Barthes, L. Bersani, P. Hamon, M. Riffaterre, I. Watt. Littérature et Réalité. Paris, Seuil Points, 1982, 119-181. [this volume also includes Roland Barthes's essay "L’Effet de réel."]

PROUST, Marcel. Du côté de chez Swann. 1913. Transl. C.K. Scott Moncrieff. Swann's Way. London: Chatto \& Windus, 1922; repr. paperback 1966.

STENGEL, Richard. «1-900-AURAL-SEX », Time Magazine, February 3, 1992, 59-60.

\section{NOTES}

i. Christine Brooke-Rose offers a useful discussion of both Hamon's and Barthes's famous texts, especially in chapter 4 of her book. 
ii. “Bayle's magnificent title had reminded me of Debussy's firm precept-which, unfortunately, I had completely failed to apply as a music student, spending whole days in fact in the listening room of Eastman's Sibley Music Library with a pair of heavy, greasy headphones on, following the score of La Mer and unsuccessfully trying to master its technical secrets, only partially convinced, as the miniature score's thousands of unenlightening notes flew by, by my own theory that the abruptly chopped-off crescendi that Debussy used to create his fantastic open-boat effects of crested loomings and tossings collapsing cyclically into earlier states and then rising up again could be explained by his several early trips to Russia, where the tape-played-backward sounds that to the Western ear are characteristic of Russian speech might have inspired him to use the orchestra to simulate inhalational inversions of those traditional phrasal envelopes which build toward or retreat from a cymbal-assisted climax, effects that Stravinsky, though a native speaker, merely appropriated in the chopped gong rolls near the end of the Rite- [...]" (Room Temperature, 52). In these lines-which do not even correspond to a complete sentencethe two dashes function as musical rests, allowing the reader to breathe.

iii. Ostioles: small bodily apertures, orifices or pores (Webster). Baker often plays with contrasts and is fond of inserting scientific terms within a more banal context.

\section{ABSTRACTS}

This paper argues that the proliferating descriptive passages in Nicholson Baker's novels seem to short-circuit narrative progression instead of being mere additives to the narrative, in a textual exploration which blurs the traditional distinction between description and narration.

The essay focuses on three of Baker's novels and comments on the evolution in Baker's work between 1988 and 2003, from the exuberant description of objects in The Mezzanine (1988), to a more intimate rehistoricizing of the object as a trace of the narrator's experience as a family man in Room Temperature (1990), to the repeated encoding of daily life as an ever-renewed mystery in A Box of Matches (2003).

Dwelling on the various strategies at work in Baker's descriptions (such as his frequent experiment with conjunction and disjunction, or his particular use of metaphor and metonymy), this paper also shows how the humorous defamiliarization of the visible contributes to the resistance of the texts. From the emphasis on material objects (and the body) to that on the materiality of signifiers, this leads to a discussion of the metatextual dimension of description.

\section{AUTHOR}

\section{FRANÇOISE SAMMARCELLI}

Université Paris-Sorbonne 